\title{
The pseudodichotomous Dasya sylviae sp. nov. (Delesseriaceae, Ceramiales) from 60-90 m mesophotic reefs off Bermuda
}

\author{
Craig W. SCHNEIDER ำ 1,*, Margaret M. CASSIDY ${ }^{2}$ \& Gary W. SAUNDERS ${ }^{\circledR} 3$ \\ 1,2 Department of Biology, Trinity College, Hartford, CT 06106, USA. \\ ${ }^{3}$ Centre for Environmental \& Molecular Algal Research, Department of Biology, \\ University of New Brunswick, Fredericton, New Brunswick E3B 5A3, Canada. \\ ${ }^{*}$ Corresponding author: cschneid@trincoll.edu \\ 2Email: margaret.cassidy@trincoll.edu \\ ${ }^{3}$ Email: gws@unb.ca
}

\begin{abstract}
The red alga Dasya sylviae C.W.Schneid., M.M.Cassidy \& G.W.Saunders sp. nov. is described from mesophotic depths of 60-90 m off Bermuda. Genetic sequences (COI-5P, $r b c \mathrm{~L}$ ) and morphological characteristics show that this species is distinct from other known pseudodichotomous species of Dasya. Of ten current species in the genus reported from Bermuda, only three, D. collinsiana M.Howe, D. cryptica C.W.Schneid., Quach \& C.E.Lane and D. punicea (Zanardini) Menegh., share the overall pattern of pseudodichotomous branching in their axes; however, key morphological features easily distinguish them from $D$. sylviae sp. nov. The species most similar in habit to D. sylviae sp. nov. is D. crouaniana J.Agardh (type locality West Indies), but it bears shorter pseudolateral branches, and broader and longer tetrasporangial stichidia than the new species. Unique among the species of Dasya, D. sylviae sp. nov. lacks post-sporangial cover cells in tetrasporangial stichidia.
\end{abstract}

Keywords. Western Atlantic, Dasya, mesophotic zone, Rhodophyta.

Schneider C.W., Cassidy M.M. \& Saunders G.W. The pseudodichotomous Dasya sylviae sp. nov. (Delesseriaceae, Ceramiales) from 60-90 m mesophotic reefs off Bermuda. European Journal of Taxonomy 751: 24-37. https://doi.org/10.5852/ejt.2021.751.1377

\section{Introduction}

Since joining the 2016 Nekton XL Catlin cruise of the R/V Baseline Explorer, the mesophotic collections of macroalgae taken off the coast of Bermuda have yielded a growing list of species new to science (Richards et al. 2018; Schneider et al. 2018, 2019a, 2019b, 2020). In the present paper, we report another new species, this a member of the genus Dasya C.Agardh that was abundantly collected at several offshore reef sites from depths of 60-90 m (Stefanoudis et al. 2018: fig. 53, as Dasya sp.).

The genus Dasya presently hosts 90 species from throughout the world's temperate and tropical seas (Guiry \& Guiry 2020). Its axial growth is sympodial with a main leading axis being continually displaced to one side by a new axis forming from a lateral bud near the apex. The resulting lateral axis takes over as the new main axis, a pattern that is repeated over and over in axial development (Parsons 1975). 
Based on appearance and not development, species of Dasya mostly look to have alternate indeterminate branching patterns. However, some species of Dasya have sympodial branching patterns that appear to be dichotomous or pseudodichotomous (subdichotomous), and they are described as having this type of branching (e.g., Schneider et al. 2017; Howe 1918; Huisman 2018). In these species, the former main axis is not as suppressed by the newly produced lateral axis as in the case of most species of Dasya and often grows nearly as long as the new leading axis, in some species to a greater degree than in others. Of the ten species historically reported from Bermuda (Schneider 2003; Schneider et al. 2017), only three, D. collinsiana M.Howe, D. cryptica C.W.Schneid., Quach \& C.E.Lane and D. punicea (Zanardini) Menegh., have an at least partial pseudodichotomous branching pattern appearance of their indeterminate axes. A morphological comparison was conducted to compare all of the known large species of the genus demonstrating mostly or partially pseudodichotomous branching with collections discovered in deep water off Bermuda demonstrating pseudodichotomous branching. Using both morphological comparisons and molecular data from the offshore samples, we were able to determine that the mesophotic specimens represent a species of Dasya new to science.

\section{Material and methods}

On the 2016 Nekton XL Catlin cruise of the R/V Baseline Explorer (BEX) off the coast of Bermuda, collections from living low-profile reefs in the mesophotic zone (Stefanoudis et al. 2018) were made by a team of technical rebreather divers (Global Underwater Explorers (GUE), High Springs, Florida, USA) equipped with closed-circuit JJ-CCR CE Edition rebreathers (JJ-CCR ApS, Copenhagen, Denmark) modified to GUE configuration, and Triton 1000-2 class submersibles (Vero Beach, Florida, USA) with mechanical collecting arms. Approximately 30 specimens of a common species of Dasya were taken at five collecting sites from depths of 60-90 m. Vouchers of type specimens are deposited in the herbaria noted in the Material examined section below; herbarium abbreviations follow the online Index Herbariorum (Thiers, continuously updated). Collection site locations on the $B E X$ were recorded using a Beier Radio DP1 (dynamic positioning, Beier Integrated Systems, Mandeville, Louisiana, USA) to receive shipboard GPS. After living specimens were chosen for DNA analysis, they were photographed using a Canon Powershot s90 digital camera (Canon Inc., Tokyo, Japan), and fragments of each were then dried in silica gel for later DNA extraction. The remainder of the DNA specimens were dried on herbarium paper as permanent vouchers. Hand-cut sections were mounted in $30 \%$ corn syrup with acidified $1 \%$ aniline blue in a ratio of 20:1. Dried specimens were scanned on an Epson ET-2650 scanner (Seiko Epson Corporation, Suwa, Nagano, Japan), and photomicrographs were taken using a Zeiss Axioskop 40 microscope (Oberkochen, Germany) equipped with a Spot Idea 28.2 5MP digital camera (Diagnostic Instruments, Sterling Heights, Michigan, USA).

Specimens generated for use in our molecular analysis are listed in Table 1. When quick drying single or multiple isolates of associated field collection numbers, the silica gel samples were designated with unique 'BDA' numbers. DNA extractions of BDA numbers followed Saunders \& McDevit (2012) and PCR amplification and sequencing of COI-5P and $r b c \mathrm{~L}$ were as detailed in Saunders \& Moore (2013). These markers initially identified five specimens assignable to a new genetic group. To place this new species into a wider phylogenetic context, additional COI-5P and $r b c \mathrm{~L}$ sequences were generated for a variety of species of Dasya and the taxonomically related genera Dasysiphonia I.K.Lee \& J.A. West, Heterosiphonia Mont. and Rhodoptilum J.Agardh from Canada, Australia and the US (Table 1). To expand further our analyses, COI-5P and $r b c \mathrm{~L}$ data were also downloaded from GenBank for additional taxonomically related species, and their accession numbers are included in Fig. 1. Two single-gene alignments were generated: COI-5P with 28 sequences of $664 \mathrm{bp}$ (base pairs) and $r b c \mathrm{~L}$ with 36 sequences and $1272 \mathrm{bp}$. These alignments were analysed separately in Geneious ver. 2021.0.1 (https://www.geneious.com; Kearse et al. 2012) with maximum likelihood (GTR $+\mathrm{I}+\mathrm{G})$ using RAxML (Stamatakis 2014) with partitioning by codon and 500 bootstrap replicates. Since no conflicts were detected, a concatenated COI-5P and 


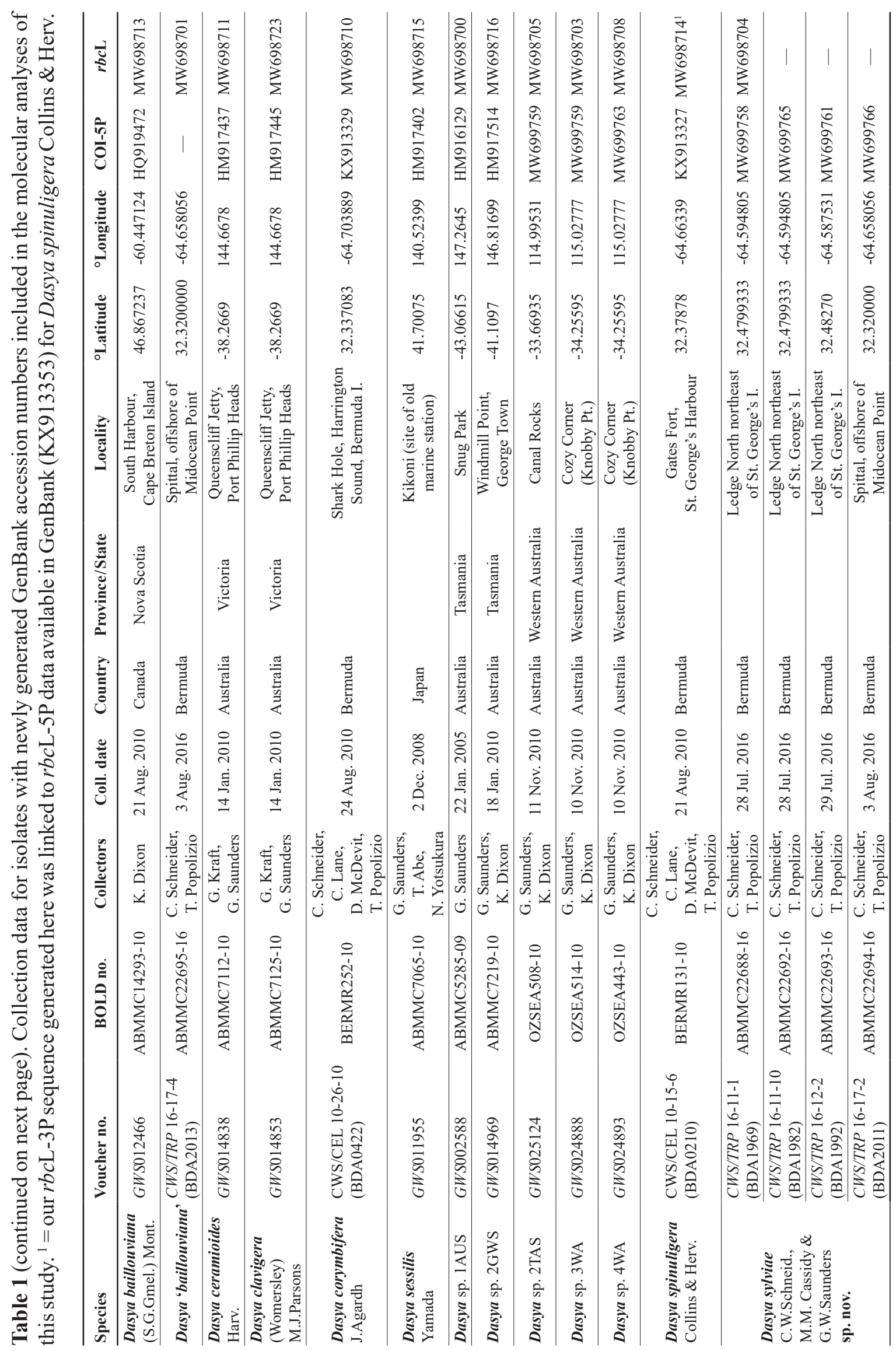




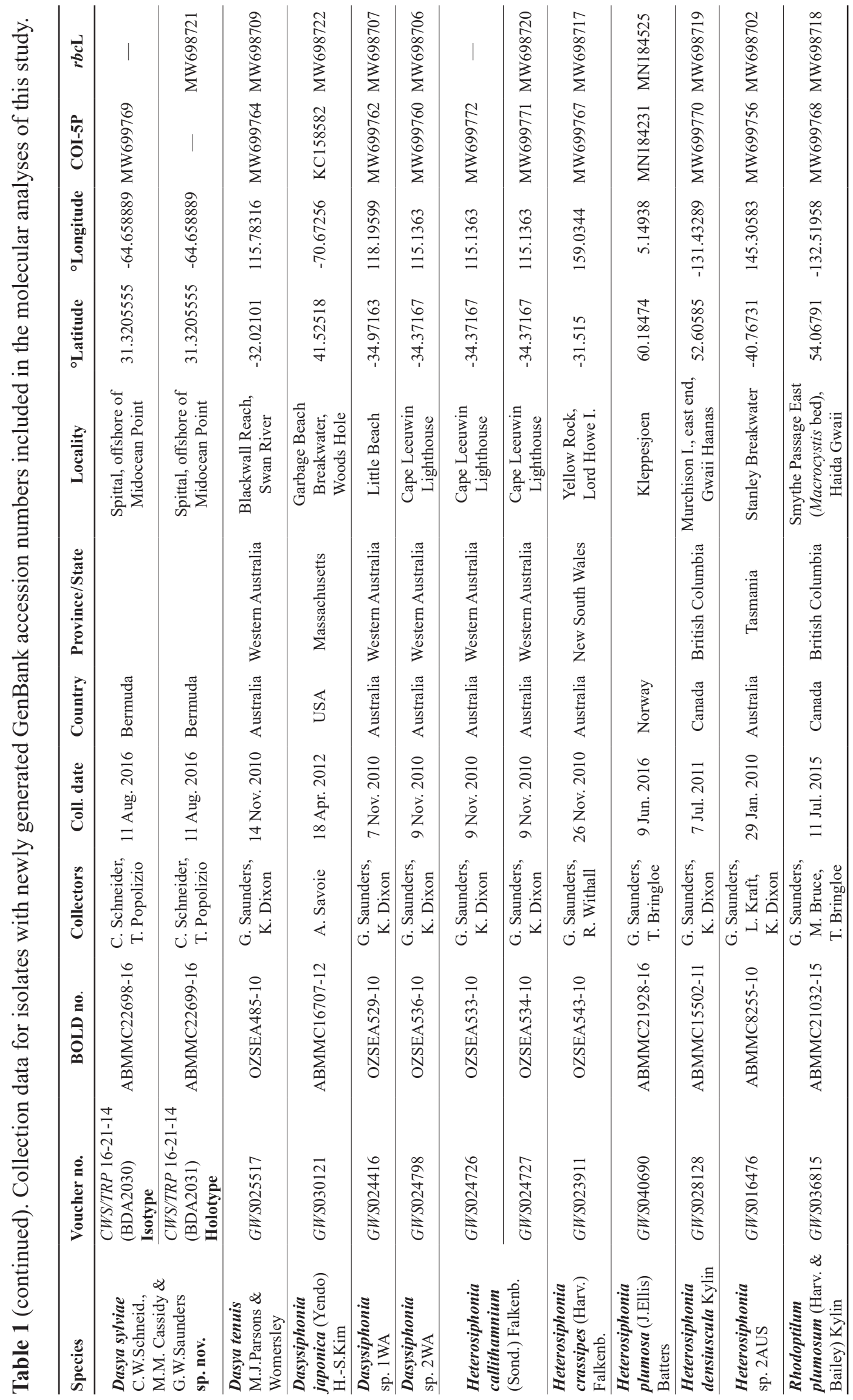


$r b c \mathrm{~L}$ alignment was constructed (38 sequences, $1936 \mathrm{bp}$ ) with analyses as described for the single gene alignments, but with partitioning by gene and codon and with 1000 bootstrap replicates (Fig. 1). In all cases, the trees were rooted on the lineage defined as the Heterosiphonia group (Choi et al. 2002).

\title{
Results
}

\section{Phylogenetic analysis}

In the speciose genus Dasya worldwide, there is a total of eight known corticated species taller than $3 \mathrm{~cm}$ at maturity that bear indeterminate axes appearing mostly or partially pseudodichotomously branched. A comparative review of these species is summarized in Table 2 . None of these bear a suite of characteristics that is comparable with the mesophotic specimens collected off Bermuda.

We successfully generated COI-5P (664 bp) for five individuals of this novel species and all had identical sequences except for one substitution in BDA2011, or $0-0.15 \%$ divergence within this species. The nearest neighbor identified through a BLAST search in GenBank was Dasya adela Heggøy, Rueness \& Sjøtun that demonstrated a $6 \%$ divergence. Similarly, we generated an $r b c$ L sequence for two specimens, which were identical over 1358 bp and $2.9 \%$ divergent from $D$. adela. Phylogenetic analyses placed the new genetic group solidly in a clade with $D$. adela and an undescribed species from the euphotic zone off Bermuda (Fig. 1, Dasya sp. 1Bda). Of further note, none of the genera included in the current tree were monophyletic except for the monospecific Rhodoptilum, which nonetheless fell solidly in a group with the generitype of Dasya, D. baillouviana (S.G.Gmel.) Mont. (Fig. 1). Clearly considerable taxonomic work remains to be done on the genera included in our phylogenetic analyses, but this does not detract from our clear discovery of a novel species best included in the genus Dasya. Therefore, based upon our molecular comparisons and phylogenetic analysis, we here describe the following unique mesophotic species of Dasya for Bermuda and the western Atlantic.

\section{Taxonomic treatment}

\author{
Phylum Rhodophyta Wettst. \\ Subphylum Eurhodophytina G.W.Saunders \& Hommers. \\ Class Florideophyceae Cronquist \\ Subclass Rhodymeniophycidae G.W.Saunders \& Hommers. \\ Order Ceramiales Oltm. \\ Family Delesseriaceae Bory \\ Subfamily Dasyoideae De Toni \\ Genus Dasya C.Agardh nom. cons.
}

Dasya sylviae C.W.Schneid., M.M.Cassidy \& G.W.Saunders sp. nov.

Fig. 2

\section{Diagnosis}

Differing from most species of Dasya by its pronounced pseudodichotomous branching pattern (Fig. 2AC), and from its most similar congener in habit, D. crouaniana J.Agardh, by its longer pseudolaterals, narrower and shorter tetrasporangial stichidia and axes fully covered with pseudolaterals to barely denuded proximal axes. The new taxon differs from all species of Dasya by its lack of post-sporangial cover cells.

\section{Etymology}

The species is named after Dr Sylvia A. Earle, pioneering phycologist, scientist and open-water diver, 50 years after she led the first all-female team of aquanauts in Tektite II on the floor of the Caribbean Sea (Earle 1972a, 1972b). 


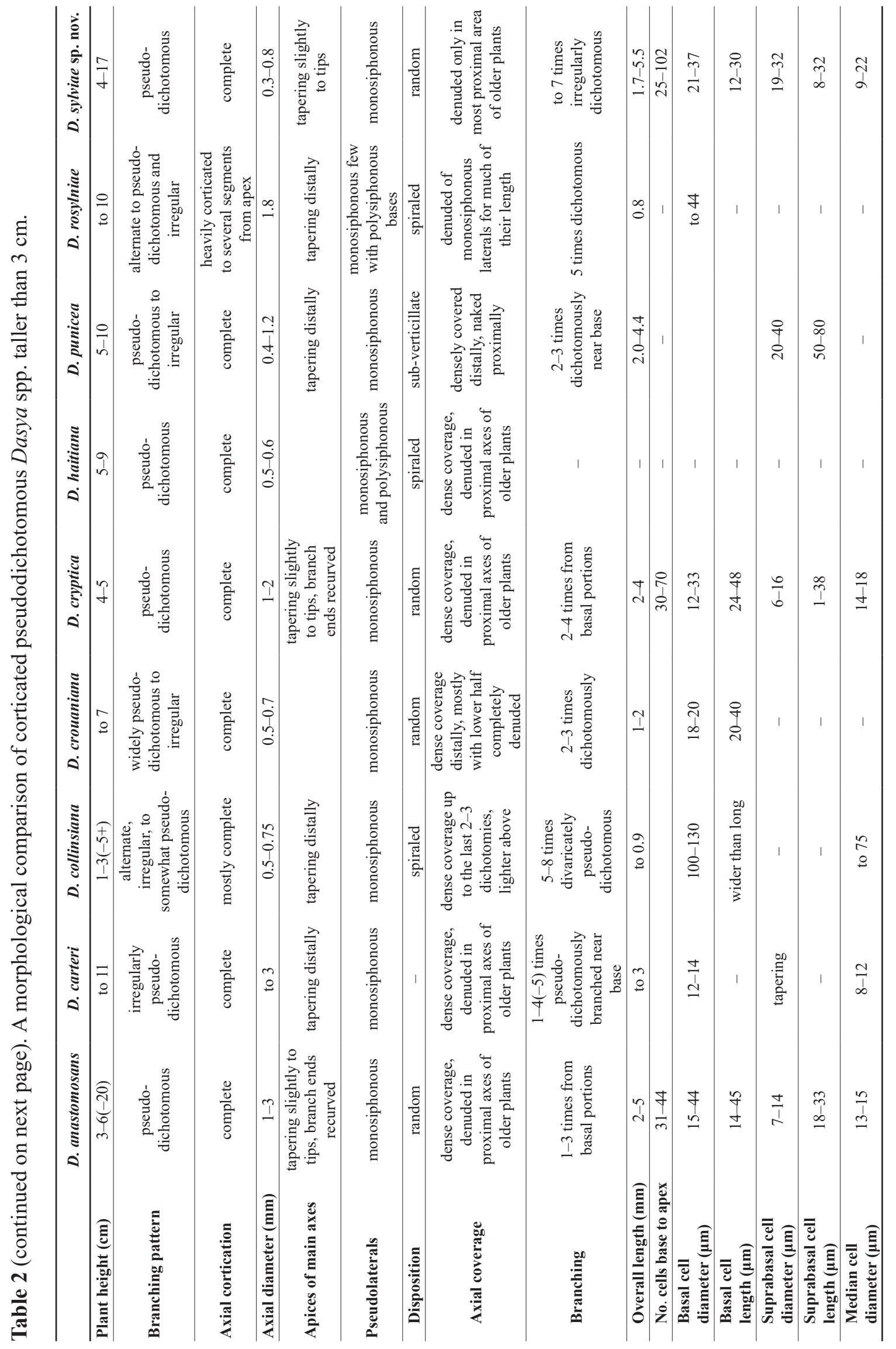




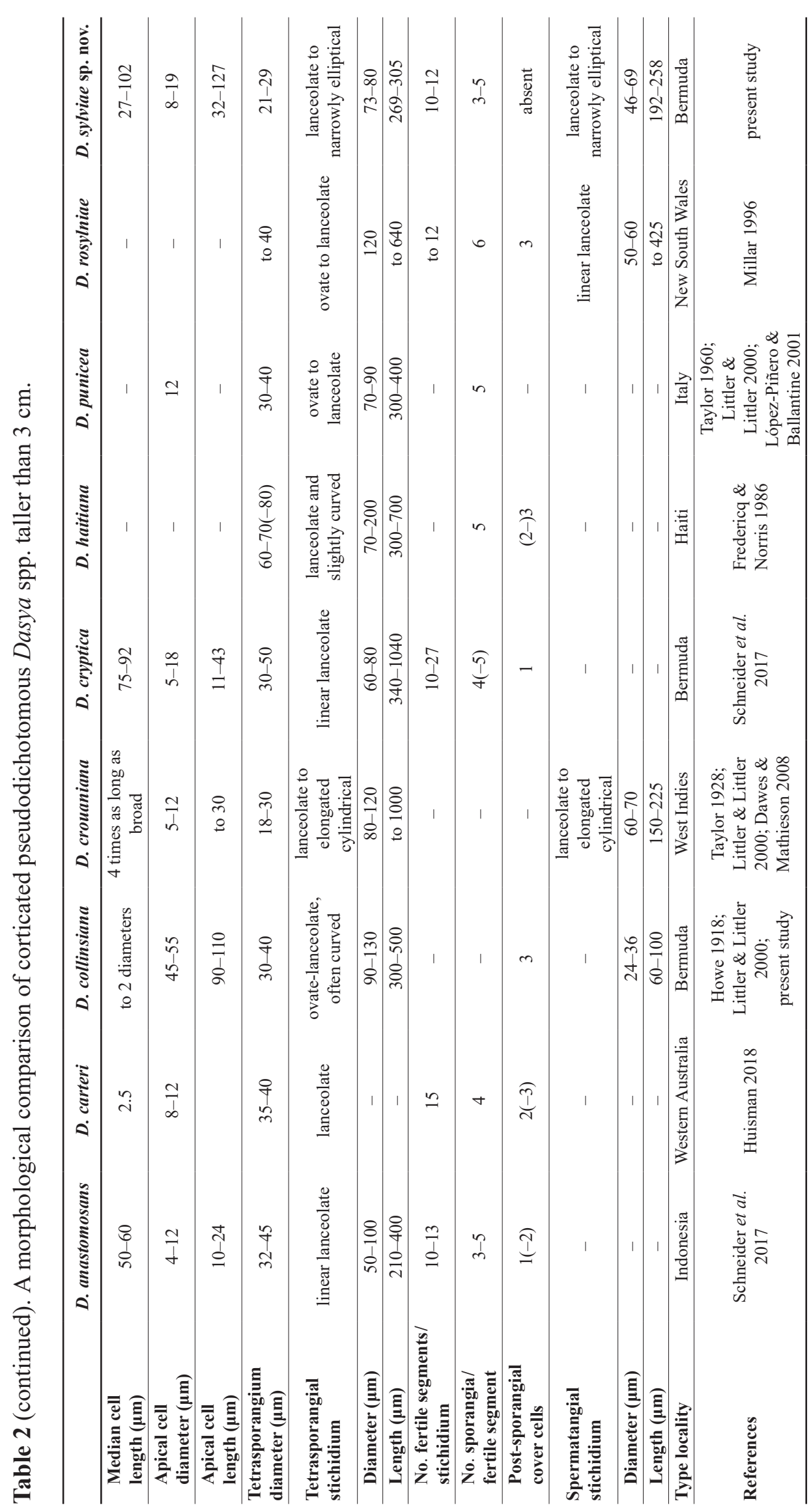




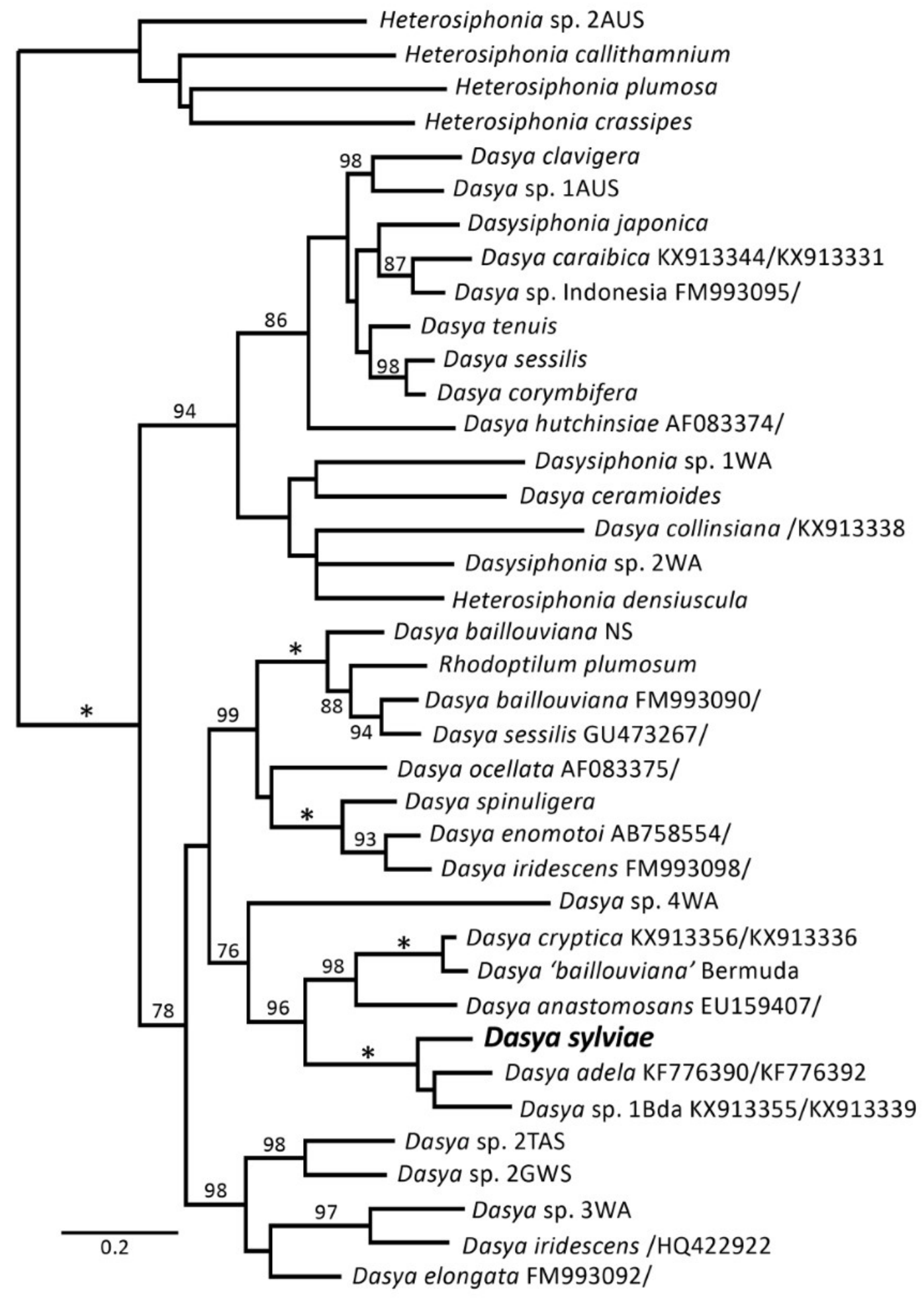

Fig. 1. Concatenated COI-5P and $r b c \mathrm{~L}$ RAxML tree, partitioned by gene and codon, GTR $+\mathrm{I}+\mathrm{G}$ with 1000 bootstrap replications (only bootstrap values $>75 \%$ shown). Asterisks $(*)$ denote $100 \%$ bootstrap support. Sequences taken from GenBank are indicated by including their accession numbers in parentheses ( $r b c \mathrm{~L} / \mathrm{COI}-5 \mathrm{P})$. The novel genetic group, Dasya sylviae sp. nov., is presented in bold type. 


\section{Material examined}

Type

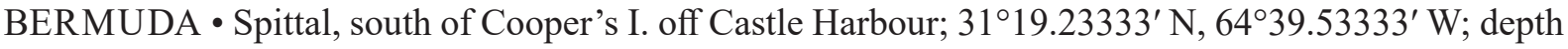
63.8 m; on rhodoliths; 11 Aug. 2016; Schneider \& Popolizio 16-21-14; GenBank nos: MW698721 (holotype), MW699769 (isotype); holotype (Fig. 2A): MICH [BDA2031]; isotypes (Fig. 2B-C): Bermuda Natural History Museum, MICH, NY, UNB, US, Herb. CWS [BDA2030].

\section{Additional material}

BERMUDA - Ledge north northeast of St. George's I.; 32²8.79600' N, 64³5.68833' W; depth 90 m; 28 Jul. 2016; Schneider \& Popolizio 16-11-1, $\oplus$ [BDA1969] • loc. cit.; depth 60 m; 28 Jul. 2016; Schneider \& Popolizio 16-11-10 [BDA1982] • loc. cit.; 32²8.96200' N, 64³5.25183’ W; depth 90 m; 29 Jul. 2016, Schneider \& Popolizio 16-12-2 [BDA1992] - Spittal, offshore of Midocean Point; 32 $19.20000^{\prime}$ N, 64³9.48333' W; depth 62.7 m; 3 Aug. 2016; Schneider \& Popolizio 16-17-2 [BDA2011].

\section{Description}

Plants epilithic, erect to $17 \mathrm{~cm}$ tall, carmine red, arising from small discoidal holdfasts; indeterminate axes sympodially branched, appearing pseudodichotomously branched throughout, only slightly tapering from base to apex (Fig. 2A-C), 0.3-0.8 mm diam. in median to lower portions and completely corticated by rhizoidal downgrowth (Fig. 2D); indeterminate axes densely covered throughout with determinate, lightly pigmented, monosiphonous dichotomously branched axes (pseudolaterals; Fig. 2E), except in some older plants in the most basal portions; pseudolaterals $1.7-5.5 \mathrm{~mm}$ in length, 25-91 cells from base to apex, irregularly dichotomously branched from the first to the seventh cell of the pseudolateral, upper portions unbranched and slightly tapering (Fig. 2E); basal cells of pseudolaterals initially globose to ellipsoid (Fig. 2D), 21-37 $\mu \mathrm{m}$ diam. and 12-30 $\mu \mathrm{m}$ long, then slightly elongating; suprabasal cells 19-32 $\mu \mathrm{m}$ diam. and 8-32 $\mu \mathrm{m}$ long, elongating more centrally, 9-22 um diam. and 27-102 $\mu \mathrm{m}$ long, and reaching greatest lengths distally, $8-19 \mu \mathrm{m}$ diam. and 32-127 $\mu \mathrm{m}$ long; tetrasporangial stichidia single, borne terminally on 3-7-celled unbranched pseudolaterals (Fig. 2F) or terminating basal dichotomies of pseudolaterals (Fig. 2G), lanceolate to narrowly elliptical in outline (Fig. 2F-G), 73-80 $\mu \mathrm{m}$ diam. and 269-305 $\mu \mathrm{m}$ in length at maturity, composed of 10-12 fertile segments, acropetally producing then releasing sporangia (Fig. 2F-G); sporangia globose, 21-29 $\mu \mathrm{m}$ diam., tetrahedrally divided, $3-5$ per fertile segment, sporangia borne on 2-celled whorled branches, post-sporangial cover cells lacking (Fig. 2F); one to two spermatangial stichidia terminating a basal dichotomy on 4-10-celled pedicels (pseudolaterals), narrowly elliptical to lanceolate in outline (Fig. 2H), 46-69 $\mu \mathrm{m}$ diam. and 192-258 $\mu \mathrm{m}$ in length at maturity; carpogonial branches and cystocarps unknown.

\section{Distribution and habitat}

At present, endemic to mesophotic reefs off Bermuda, western Atlantic Ocean.

\section{Discussion}

The genus Dasya is characterized by the development of 2-4 pre- and post-sporangial cover cells that partially cover tetrasporangia in their stichidium (Parsons 1975). Dasya sylviae sp. nov. appears to be unique among its congeners as it completely lacks these cover cells, thus tetrasporangia sit naked on their whorl branches (Table 2, Fig. 2G). Among the presently accepted 90 species of Dasya (Guiry \& Guiry 2020), only eight corticated species of Dasya that reach at least $3 \mathrm{~cm}$ tall at maturity, including three from Bermuda (D. collinsiana, D. cryptica and D. punicea), appear to share an overall axial pattern of pseudodichotomous branching with D. sylviae sp. nov. (Table 2, Fig. 2A-C). However, key morphological characteristics easily distinguish them from the new species presented here. Among the few species with longer pseudolaterals approaching the length of those in the new species (to $5.5 \mathrm{~mm}$ 

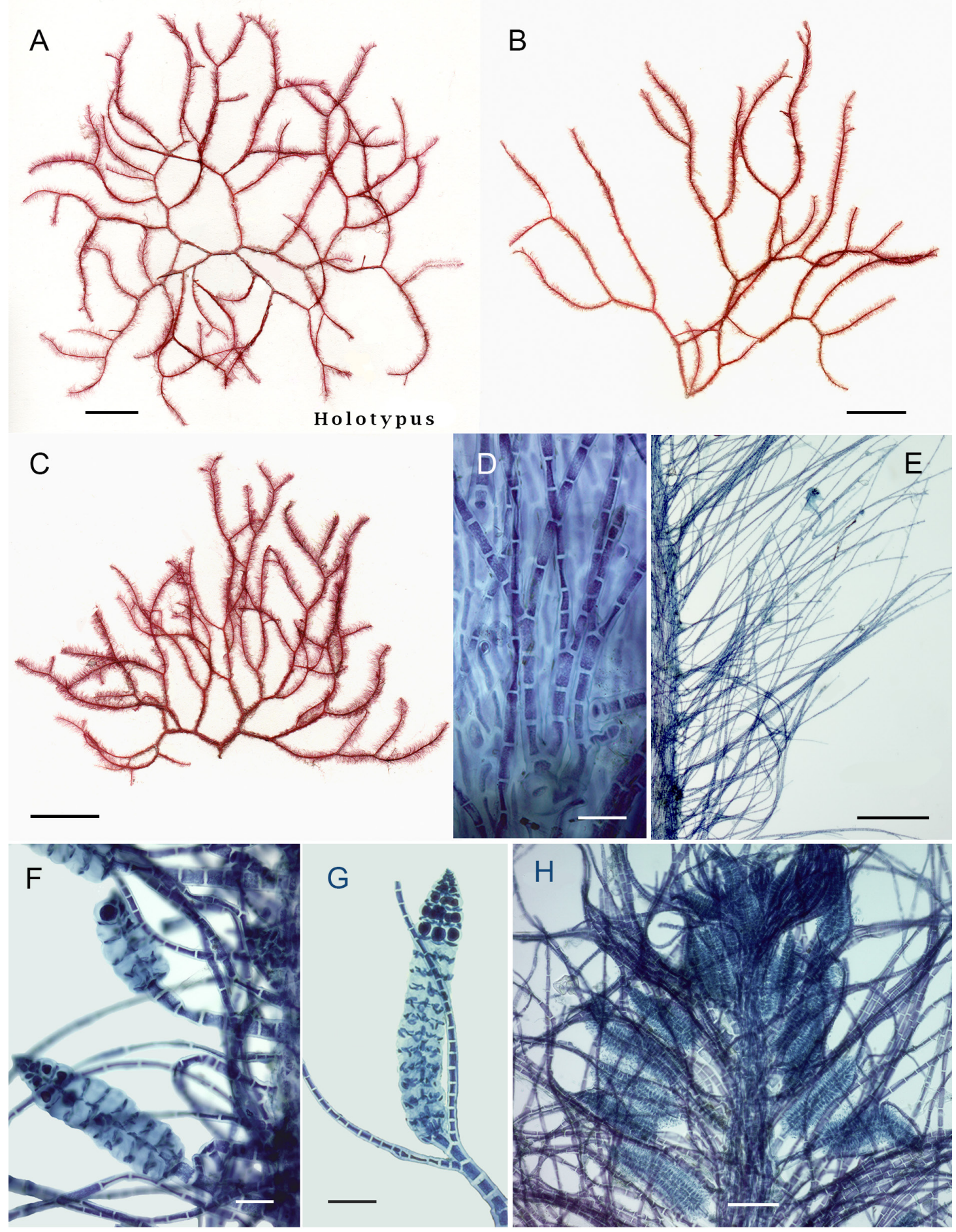

Fig. 2. Dasya sylviae C.W.Schneid., M.M.Cassidy \& G.W.Saunders sp. nov. A. Holotype specimen, CWS/TRP 16-21-14 (BDA2031); MICH. B-C. Isotype specimens. D. Whole mount near apex with rhizoidal cortication and pseudolateral branches, CWS/TRP 16-17-2. E. Whole mount of axis with emerging pseudolaterals, CWS/TRP 16-21-14. F. Tetrasporangial stichidia on long pedicels, CWS/TRP 16-11-1 (BDA1969). G. Acropetal development in a tetrasporangial stichidium at base of pseudolateral branch with whorled two-celled branches bearing sporangia that lack post-sporangial cover cells, CWS/TRP 16-11-1 (BDA1969). H. Spermatangial stichidia at axis apex, $C W S / T R P$ 16-21-14. Scale bars: A-C = $2 \mathrm{~cm}$; D, $\mathrm{F}=50 \mu \mathrm{m} ; \mathrm{E}=500 \mu \mathrm{m} ; \mathrm{G}-\mathrm{H}=100 \mu \mathrm{m}$. 
long), D. anastomosans (Weber Bosse) M.J.Wynne and D. cryptica demonstrate a short bushy habit with more dense pseudolateral growth, larger tetrasporangia and longer stichidia (Table 2).

The species most similar to Dasya sylviae sp. nov. in overall habit is D. crouaniana (type locality West Indies), but the latter species is characterized by its striking loss of deciduous pseudolaterals in the lower half of its main axes contrasted by densely enveloped distal portions as illustrated in Taylor (1928: pl. 35 fig. 5; 1960: pl. 71 fig 1). These pseudolaterals are shorter in length $(1-2 \mu \mathrm{m})$ but more densely packed than the longer ones of $D$. sylviae sp. nov. $(1.7-5.5 \mu \mathrm{m})$. Furthermore, the tetrasporangial stichidia of $D$. crouaniana are both longer and broader (to $1 \mathrm{~mm} \times 80-120 \mu \mathrm{m}$ ) than in the new species (269-305 $\mu \mathrm{m} \times 73-80 \mu \mathrm{m})$. Unfortunately, we do not have genetic information for this species, but its morphological differences distinguish it from $D$. sylviae sp. nov.

While Dasya punicea (type locality Venice) appears to be somewhat similar to D. sylviae sp. nov. in habit, the Mediterranean species can be differentiated by its subverticillate pseudolaterals, slightly longer tetrasporangial stichidia (300-400 $\mu \mathrm{m}$ vs 269-305 $\mu \mathrm{m})$ and slightly larger tetrasporangia (30-40 $\mu \mathrm{m}$ vs 21-29 $\mu \mathrm{m}$ ). Its long pseudolaterals (to $4.4 \mathrm{~mm}$ ) are reminiscent of the new species. Dasya punicea was reported from Bermuda by Collins \& Hervey (1917) who stated that their specimens had a tendency to issue ramelli [pseudolaterals] "in more or less distinct whorls," a condition dissimilar to that in specimens from the eastern Atlantic where the pseudolaterals were spirally arranged (Maggs \& Hommersand 1993). Ballantine \& Aponte (2004) argued that the entity first reported in the western Atlantic from Bermuda by Collins \& Hervey (1917) as D. punicea was different from eastern Atlantic and Mediterranean isolates. Three archival specimens left by A. Hervey as D. punicea (Collins \& Hervey 1917; NY 2178604) are an admixture of two species on a single sheet, one representing a young Dasya spinuligera Collins \& Herv., the remaining representative of Wrangelia C.Agardh (Wrangeliaceae J.Agardh), not Dasya.

The mesophotic specimens described here as a new taxon were collected along with two other species of Dasya at these depths, D. cf. baillouviana (S.G.Gmel.) Mont. (58-77 m) and D. spinuligera $(60 \mathrm{~m})$. Unlike $D$. sylviae sp. nov., both of these species with different and distinctive morphologies are also known on shallow subtidal reefs in Bermuda. Including D. collinsiana, D. cryptica and D. spinuligera, D. sylviae sp. nov. represents the fourth species of the genus with its type locality in Bermuda (Collins \& Hervey 1917; Howe 1918; Schneider et al. 2017).

Genetically, Dasya sylviae sp. nov. falls in a clade with the recently described $D$. adela, a species discovered in a landlocked fjord in Norway (Sjøtun et al. 2016), and the alternately to irregularly branched Dasya sp. 1Bda from the shallow subtidal of Bermuda (Schneider et al. 2017) (Fig. 1). Dasya adela is significantly smaller (to $3 \mathrm{~cm}$ ) than D. sylviae sp. nov., and develops "radially to irregularly set side [indeterminate] branches" (Sjøtun et al. 2016) and cover cells for tetrasporangia in stichidia. These two species are morphologically easy to differentiate even if their habitats weren't also disparate.

\section{Acknowledgements}

The XL Catlin Deep Ocean Survey, Nekton's mission to the Northwest Atlantic and Bermuda aboard the $B E X$, allowed for the 2016 collections. Nekton gratefully acknowledges the support of XL Catlin and the Garfield Western Foundation. Work on the R/V Baseline Explorer (BEX) would have been impossible without the assistance of Capt. Larry Bennett and his crew, Brownies Global Logistics, Triton Submersibles and pilots, and the several volunteer technical divers of Global Underwater Explorers led by Dr Todd Kincaid. We thank Dr Thea Popolizio for helping collect aboard the $B E X$ and multiple members of the Saunders lab over the years, notably Cody Brooks and Tanya Moore, for sequencing the specimens of Dasya reported on here. Christopher Flook of the Bermuda Institute of Ocean Sciences (BIOS) and Roger Simmons of the Bermuda Aquarium, Natural History Museum and Zoo (BAMZ) provided logistical support while in Bermuda. The genetic work at UNB was supported by Discovery and 
Accelerator grants to GWS from the Natural Sciences and Engineering Research Council of Canada, as well as funding from the Canada Foundation for Innovation, the New Brunswick Innovation Foundation, and the Nekton Foundation. This is contribution no. 286 to the Bermuda Biodiversity Project (BBP) of BAMZ, Department of Environment \& Natural Resources, and Nekton contribution no. 19.

\section{References}

Ballantine D.L. \& Aponte N.E. 2004. Dasya abbottiana sp. nov. (Dasyaceae, Rhodophyta) from Puerto Rico, Caribbean Sea. Cryptogamie, Algologie 25: 409-417.

Choi H.-G., Kraft G.T., Lee I.K. \& Saunders G.W. 2002. Phylogenetic analyses of anatomical and nuclear SSU rDNA sequence data indicate that the Dasyaceae and Delesseriaceae (Ceramiales, Rhodophyta) are polyphyletic. European Journal of Phycology 37 (4): 551-569.

https://doi.org/10.1017/S0967026202003967

Collins F.S. \& Hervey A.B. 1917. The algae of Bermuda. Proceedings of the American Academy of Arts \& Sciences 53: 1-195. https://doi.org/10.2307/20025740

Dawes C.J. \& Mathieson A.C. 2008. The Seaweeds of Florida. University Press of Florida, Gainesville.

Earle S.A. 1972a. Introduction. In: Collette B.B. \& Earle S.A. (eds) Results of the Tektite Program: Ecology of Coral Reef Fishes: 1-11. Natural History Museum, Los Angeles County Science Bulletin 14.

Earle S.A. 1972b. The influence of herbivores on the marine plants of Great Lameshur Bay, with an annotated list of plants. In: Collette B.B. \& Earle S.A. (eds) Results of the Tektite Program: Ecology of Coral Reef Fishes: 17-44. Natural History Museum, Los Angeles County Science Bulletin 14.

Fredericq S. \& Norris J.N. 1986. The structure and reproduction of Dasya haitiana sp. nov. (Dasyaceae, Rhodophyta) from the Caribbean Sea. Phycologia. 25: 185-196.

https://doi.org/10.2216/i0031-8884-25-2-185.1

Guiry M.D. \& Guiry G.M. 2020. AlgaeBase. Available from http://www.algaebase.org [accessed 15 Apr. 2020].

Howe M.A. 1918. Class 3. Algae. In: Britton N.L. (ed.) Flora of Bermuda: 489-540. Charles Scribner's Sons, New York.

Huisman J.M. 2018. Algae of Australia. Marine Benthic Algae of North-Western Australia. 2. Red Algae. ABRS \& CSIRO Publishing, Canberra and Melbourne.

Kearse M., Moir R., Wilson A., Stones-Havas S., Cheung M., Sturrock S., Buxton S., Cooper A., Markowitz S., Duran C., Thierer T., Ashton B., Meintjes P. \& Drummond A. 2012. Geneious Basic: an integrated and extendable desktop software platform for the organization and analysis of sequence data. Bioinformatics 28 (12): 1647-1649. https://doi.org/10.1093/bioinformatics/bts 199

Littler D.S. \& Littler M.M. 2000. Caribbean Reef Plants. An Identification Guide to the Reef Plants of the Caribbean, Bahamas, Florida and Gulf of Mexico. OffShore Graphics, Inc., Washington.

López-Piñero I.Y. \& Ballantine D.L. 2001. Dasya puertoricensis sp. nov. (Dasyaceae, Rhodophyta) from Puerto Rico, Caribbean Sea. Botanica Marina 44 (4): 337-344. https://doi.org/10.1515/BOT.2001.043

Maggs C.A. \& Hommersand M.H. 1993. Seaweeds of the British Isles. Vol. 1 Rhodophyta. Part 3 A Ceramiales. The Natural History Museum. HMSO Publications, London.

Millar A.J.K. 1996. Dasya roslyniae sp. nov. (Dasyaceae, Rhodophyta), with a discussion on generic distinctions among Dasya, Eupogodon, Rhodoptilum, and Pogonophorella. Journal of Phycology 32: 145-157. https://doi.org/10.1111/j.0022-3646.1996.00145.x 
Parsons M.J. 1975. Morphology and taxonomy of the Dasyaceae and the Lophothalieae (Rhodomelaceae) of the Rhodophyta. Australian Journal of Botany 23 (4): 549-713. https://doi.org/10.1071/BT9750549

Richards J.L., Gabrielson P.W. \& Schneider C.W. 2018. Sporolithon mesophoticum sp. nov. (Sporolithales, Rhodophyta) from Plantagenet Bank off Bermuda at a depth of 178 m. Phytotaxa 385 (2): 67-76. https://doi.org/10.11646/phytotaxa.385.2.2

Saunders G.W. \& McDevit D.C. 2012. Methods for DNA barcoding photosynthetic protists emphasizing the macroalgae and diatoms. Methods in Molecular Biology 858: 207-222.

https://doi.org/10.1007/978-1-61779-591-6_10

Saunders G.W. \& Moore T.E. 2013. Refinements for the amplification and sequencing of red algal DNA barcode and RedToL phylogenetic markers: a summary of current primers, profiles and strategies. Algae 28: 31-43. https://doi.org/10.4490/algae.2013.28.1.031

Schneider C.W. 2003. An annotated checklist and bibliography of the marine macroalgae of the Bermuda islands. Nova Hedwigia 76: 275-361. https://doi.org/10.1127/0029-5035/2003/0076-0275

Schneider C.W., Quach P.K. \& Lane C.E. 2017. A case for true morphological crypsis: Pacific Dasya anastomosans and Atlantic D. cryptica sp. nov. (Dasyaceae, Rhodophyta). Phycologia 56: 359-368.

https://doi.org/10.2216/16-79.1

Schneider C.W., Lane C.E. \& Saunders G.W. 2018. A revision of the genus Cryptonemia (Halymeniales, Rhodophyta) in Bermuda, western Atlantic Ocean, including five new species and C. bermudensis (Collins et M. Howe) comb. nov. European Journal of Phycology 53: 350-368.

https://doi.org/10.1080/09670262.2018.1452297

Schneider C.W., Popolizio T.R., Kraft L.G.K. \& Saunders G.W. 2019a. New species of Galene and Howella gen. nov. (Halymeniaceae, Rhodophyta) from the mesophotic zone off Bermuda. Phycologia 58: 690-697. https://doi.org/10.1080/00318884.2019.1661158

Schneider C.W., Popolizio T.R. \& Saunders G.W. 2019b. Collections from the mesophotic zone off Bermuda reveal three species of Kallymeniaceae (Gigartinales, Rhodophyta) in genera with transoceanic distributions. Journal of Phycology 54: 415-424. https://doi.org/10.1111/jpy.12828

Schneider C.W., Peterson E.S. \& Saunders G.W. 2020. Two new species of Solieriaceae (Rhodophyta, Gigartinales) from the euphotic and mesophotic zones off Bermuda, Meristotheca odontoloma and Tepoztequiella muriamans. Phycologia 59: 177-185. https://doi.org/10.1080/00318884.2020.1719326

Sjøtun K., Heggøy E., Gabrielsen T.M. \& Rueness J. 2016. Dasya adela sp. nov. (Rhodophyta, Ceramiales), an enigmatic new Dasya from a landlocked fjord in southwest Norway. Phycological Research 64: 79-94. https://doi.org/10.1111/pre.12121

Stamatakis A. 2014. RAxML version 8: a tool for phylogenetic analyses and post-analysis of large phylogenies. Bioinformatics 30 (9): 1312-1313. https://doi.org/10.1093/bioinformatics/btu033

Stefanoudis P.V., Smith S.R., Schneider C., Wagner D., Goodbody-Gringley G., Xavier J., Rivers M., Woodall L.C. \& Rogers A.D. 2018. Deep Reef Benthos of Bermuda: Field Identification Guide. Nekton, Oxford, England. https://doi.org/10.6084/m9.figshare.7333838

Taylor W.R. 1928. The Marine Algae of Florida, with Special Reference to the Dry Tortugas. Publication 379, Carnegie Institution of Washington.

Taylor W.R. 1960. Marine Algae of the Eastern Tropical and Subtropical Coasts of the Americas. University of Michigan Press, Ann Arbor. 
Thiers B. continuously updated. Index Herbariorum: A Global Directory of Public Herbaria and Associated Staff. New York Botanical Garden's Virtual Herbarium.

Available from http://sweetgum.nybg.org/science/ih/ [accessed 1 Jul. 2020].

Manuscript received: 11 January 2021

Manuscript accepted: 15 March 2021

Published on: 27 May 2021

Topic editor: Frederik Leliaert

Desk editor: Radka Rosenbaumová

Printed versions of all papers are also deposited in the libraries of the institutes that are members of the EJT consortium: Muséum national d'histoire naturelle, Paris, France; Meise Botanic Garden, Belgium; Royal Museum for Central Africa, Tervuren, Belgium; Royal Belgian Institute of Natural Sciences, Brussels, Belgium; Natural History Museum of Denmark, Copenhagen, Denmark; Naturalis Biodiversity Center, Leiden, the Netherlands; Museo Nacional de Ciencias Naturales-CSIC, Madrid, Spain; Real Jardín Botánico de Madrid CSIC, Spain; Zoological Research Museum Alexander Koenig, Bonn, Germany; National Museum, Prague, Czech Republic. 